\title{
Maimonides on the Eternity of the World
}

\section{Introduction ${ }^{1}$}

Maimonides' stance on the creation of the world has attracted considerable debate over the centuries. Those who arrived at the conclusion that Maimonides maintains an essentially Aristotelian picture of divine governance of the world, and presents an esoteric position on all the theological issues in which God is regarded as playing a personal role in human affairs, could hardly take Maimonides' defense of creation at

1 This article has its origins in a symposium that took place at the 2008 conference of the Association of Jewish Studies, and first appeared in Jewish Philosophy: Perspectives and Retrospectives, ed. Raphael Jospe and Dov Schwartz (Brighton, MA: Academic Studies Press, 2012), 157-184. In this volume appear also an article by Kenneth Seeskin, seeking to strengthen his interpretation of Maimonides as believing in creation, together with responses to both articles on the part of Roslyn Weiss and Charles H. Manekin. In spite of the points of critique against my article on the part of both respondents (from two entirely different directions, though Roslyn Weiss shares my basic conclusion), I decided to retain the original form, aside for some minor additions and changes, without responding to the critiques. One is strongly urged to read all the articles in the volume cited above. 
face value. ${ }^{2}$ Though I belong to the camp of those who adopt an esoteric reading of Maimonides and maintain that he attempted to understand Judaism in light of Aristotelian thought-and did not seek to develop a position that took a middle course between the personal God of tradition and the impersonal God of philosophy-I confess that it is hard to read Maimonides' account of creation without feeling that he really means it. Why else would he go to such pains to defend this doctrine philosophically as well as on religious grounds? Moreover, Maimonides does not simply go through the motions of proving creation, but displays a great deal of philosophic ingenuity, and develops some solid philosophic arguments that improve upon those found in his sources, while still not abandoning the principles of Aristotelian physics to which he is committed. This is hardly the move we would expect of someone hinting at an esoteric position. The presentation of standard

2 The most important modern exponent of the esoteric reading of Maimonides is Leo Strauss; see his classic study "The Literary Character of The Guide of the Perplexed," in Essays on Maimonides, ed. Salo Baron (New York: Columbia University Press, 1941), 37-91 [reprinted in Strauss, Persecution and the Art of Writing (Glencoe: Free Press, 1952), 38-94]. For a survey of esoteric vs. exoteric readings of Maimonides' thought, see in particular Aviezer Ravitzky, "The Secrets of the Guide of the Perplexed: Between the Thirteenth and the Twentieth Centuries," in Studies in Maimonides, ed. Isadore Twersky (Cambridge, MA: Harvard University Press, 1990), 159-207. See also Howard Kreisel, "Moses Maimonides," in History of Jewish Philosophy, ed. Daniel H. Frank and Oliver Leaman (London: Routledge, 1997), 245-280. For some recent studies of Maimonides' esotericism, see Sara KleinBraslavy, King Solomon and Philosophical Esotericism in the Thought of Maimonides (Jerusalem: Magnes Press, 1996) (Heb.); Yair Loberbaum, "On Contradictions, Rationality, Dialectics and Esotericism in Maimonides' Guide of the Perplexed," Metaphysics 55 (2002): 711-750; Aviezer Ravitzky, "Maimonides: Esotericism and Philosophical Education," Daat 53 (2004): 43-62 (Heb.). For a study of this issue in medieval Jewish philosophy in general, see Moshe Halbertal, Concealment and Revelation: Esotericism in Jewish Thought and its Philosophical Implications (Princeton: Princeton University Press 2007); Dov Schwartz, Contradiction and Concealment in Medieval Jewish Thought (Ramat-Gan: Bar-Ilan University Press, 2002) (Heb.). It should be noted that even among those scholars who favor an esoteric reading of Maimonides, not all of them agree that his motive was essentially political-that is to say, to hide certain truths from the masses. See also Warren Z. Harvey, "How Leo Strauss Paralyzed the Study of the Guide of the Perplexed in the $20^{\text {th }}$ Century," Iyyun 50 (2001): $387-396$ (Heb.). For a strident attack against the esoteric reading of Maimonides in general, see Herbert Davidson, Moses Maimonides: The Man and His Works (Oxford: Oxford University Press, 2005), 387-402. 
but weak philosophic arguments to rebut the stronger arguments of your opponent is indeed a possible way of subtly alluding to an esoteric position. ${ }^{3}$ However, that a strong philosophic argument should be interpreted as not seriously held by its author-such an interpretation appears to be the product of perverse thinking.

It is easy to see the motivation of some of the medieval interpreters in making such a move, such as Joseph Ibn Kaspi and Moses Narboni, who suggest that Maimonides in fact believed in the eternity of the world and develop an esoteric reading of his statements on this issue. ${ }^{4}$ The doctrine of eternity was philosophically more respectable, and in this manner they tried to show how Maimonides was in basic agreement with the Aristotelian position, as they themselves apparently were. The modern interpreter is no longer burdened with this consideration; the opposite is the case. Maimonides' belief in creation, even creation ex nibilo, is more in keeping with contemporary science. Thus his stated position on this issue is the one that those interested in interpreting tradition in light of science should take pains to defend.

Nevertheless, I would like to advance the claim that despite all the considerable evidence to the contrary-much of it brought in painstaking detail by Kenneth Seeskin in his recent book, Maimonides on the Origin of the World 5 -Maimonides in fact secretly favored the belief in the eternity a parte ante of the world. ${ }^{6}$ The primary path I will adopt in arguing that Maimonides in essence accepts the position that he vociferously argues against is the textual one-a path long favored by

3 See Leo Strauss's masterful discussion of methods for conveying secret teachings that oppose the prevailing orthodoxy in his Persecution and the Art of Writing, 22-37.

4 See Joseph Ibn Kaspi, Maskiyot Kesef, ed. Solomon Werblunger (Frankfurt A.M., 1848), 99-101; Moses Narboni, Be'ur le-Sefer Moreb Nevukbim, ed. Jacob Goldenthal (Vienna, 1852), 23b, 34a-b, 52a [both commentaries are reprinted in Sheloshah Qadmonei Mefarshei Ha-Moreb (Jerusalem, 1961)].

5 (Cambridge: Cambridge University Press, 2005).

6 I am not claiming that Maimonides was absolutely convinced of this position and that he thought that the philosophers had in fact presented a demonstrative argument proving eternity. I am prepared to grant that Maimonides continued to entertain doubts on this issue. My claim is that he felt that the eternity of the world was the preferable position from a philosophic standpoint and was in all likelihood the esoteric position of Jewish tradition. 
the esotericists and most in keeping with Maimonides' remarks in the introduction to his treatise. ${ }^{7}$ Comments Maimonides makes in passing often do not belong to the thrust of his argument in the context in which they appear and in fact clarify his opinion on issues he discusses elsewhere. Moreover, a close look at some of his comments reveals that they in fact undermine the gist of his argument and support the position he purportedly rejects. There is a midrashic quality to such reading-looking for the textual irregularities in the Maimonidean text and then offering an interpretation that seems to fly in the face of what the text literally states, or that reads much between the lines. ${ }^{8}$ While each of these readings taken individually are open to refutation, together they seem to support the view that there is an esoteric subtext to Maimonides' treatise, which extends also to the issue of creation.

\section{The Esotericist Reading of Maimonides' Philosophy}

Let us for a moment review the gist of Maimonides' position in the Guide in regard to creation. According to Maimonides, the monotheistic idea is proven if one accepts either creation or the eternity of the world (Guide 1.71). ${ }^{9}$ God's unique existence is not the issue here. Nor

7 Maimonides writes: "If you wish to grasp the totality of what this Treatise contains, so that nothing of it will escape you, then you must connect its chapters one with another; and when reading a given chapter, your intention must be not only to understand the totality of the subject of that chapter, but also to grasp each word that occurs in it in the course of the speech, even if that word does not belong to the intention of the chapter. For the diction of this Treatise has not been chosen at haphazard, but with great exactness and exceeding precision, and with care to avoid failing to explain any obscure point. And nothing has been mentioned out of its place, save with a view of explaining some matter in its proper place" (15). All English translations are taken from the translation of Shlomo Pines (Chicago: Chicago University Press, 1963).

8 In other words, just as the midrash often focuses on the verbal "irregularities" in the biblical text, isolates them, and develops their meaning, frequently appealing to verses that deal with entirely different matters, so one must use this method in reading Maimonides. As shown in the previous note, Maimonides himself appears to counsel employing this method in reading his treatise.

9 Cf. Guide 2.1 (third proof of God's existence). One should add that for the masses, belief in creation better supports the belief in one God than does belief in eternity. The belief that the spheres existed from eternity easily leads to the belief that they are deities, the belief that according to Maimonides characterizes the ancient religion of the Sabians (Guide 3.29). This may have also served for Maimonides as an 
is the order of nature the issue, for Maimonides accepts the order of nature in its Aristotelian form even if the world is created, while rejecting the Kalām's view on this matter (Guide 1.71-72; 2.3-12). One may further argue that Maimonides regards creation as providing a better foundation for accepting the order of nature as posited by Aristotle than does the doctrine of eternity. Maimonides equates the doctrine of eternity with the doctrine of necessity, and necessity cannot adequately explain the purposive functioning of the order of nature (Guide 2.19-22). Yet it is not that creation provides a better philosophical explanation for the existence of the order of nature that is the main point Maimonides argues; rather, he asserts that creation proves that God possesses volition that is not limited to the order of nature. Only by accepting the notion of divine volition can we have revelatory religion and all the theological doctrines associated with it (Guide 2.25). The God of Aristotle has no role to play in history, is not a lawgiver, does not choose prophets to send on missions, and cannot perform miracles. Nor does Aristotle's deity reward and punish individuals in accordance with their actions. The God of Aristotle is the deity of an eternally unchanging natural order. Even if creation provides a better explanation for the existence of this order than does eternity, one hardly needs creation to posit such an order; one needs creation to posit the exceptions to the order. As Julius Guttmann succinctly notes regarding Maimonides' doctrine of creation: “It relieves Maimonides of the necessity of interpreting the religious ideas of God's activity and his relationship to the world in terms of an immanent, teleological, and largely impersonal dynamism. He can now reinvest these ideas with their original meaning, though he makes only sparing and very cautious use of this possibility." ${ }^{10}$ As Maimonides himself phrases it in Guide 2.25: "Know that with a belief in the creation of the world in time, all the miracles become possible and the Law becomes possible" (329).

important factor in upholding the doctrine of creation, even if he did privately accept it as true.

10 Philosophies of Judaism, trans. David Silverman (New York: Schocken Books, 1973), 192. 
Yet a close reading of the issues involved has led a number of interpreters of Maimonides' philosophy to conclude that he in fact interprets God's activity and His relationship to the world in terms of "an immanent, teleological, and largely impersonal dynamism." Maimonides treats prophecy as a natural phenomenon, with the caveat that God can miraculously withhold prophecy from one who is worthy to attain it. At the same time, he invalidates his own examples for the miraculous withholding of prophecy, viewing such a miracle as only a theoretical possibility that never materialized and apparently never will. In this manner he signals his essential agreement with the Aristotelian position (Guide 2.32). ${ }^{11}$ Only Mosaic prophecy and the Revelation at Sinai continue to be treated by him as supernatural phenomena, as in his earlier writings. However, in this case too there are passages in the Guide that can be interpreted as alluding to an esoteric position, which views Moses as the immediate author of the Law on the basis of the prophetic illumination he attained, and understands the Revelation at Sinai in a naturalistic manner. ${ }^{12}$ Maimonides scatters certain hints in his writings that God did not in fact personally inform Moses of each

11 For a discussion of Maimonides' three opinions concerning prophecy and the ramifications of his view of prophecy regarding the problem of creation, see Lawrence Kaplan, "Maimonides on the Miraculous Element in Prophecy," HTR 70 (1977): 233-256; Herbert Davidson, "Maimonides' Secret Position on Creation," in Studies in Medieval Jewish History and Literature, ed. Isadore Twersky (Cambridge, MA: Harvard University Press, 1979), 16-40. Warren Z. Harvey, "A Third Approach to Maimonides' Cosmogony-Prophetology Puzzle,” HTR 74 (1981): 287-301; Howard Kreisel, Prophecy: The History of an Idea in Medieval Jewish Philosophy (Dordrecht: Kluwer, 2001), 222-230; Roslyn Weiss, "Natural Order or Divine Will: Maimonides on Cosmogony and Prophecy," Journal of Jewish Thought and Philosophy 15 (2007): 1-26.

12 See Alvin Reines, "Maimonides' Concept of Mosaic Prophecy," HUCA 40 (1969): 325-362; Kalman Bland, "Moses and the Law According to Maimonides," in Mystics, Philosophers and Politicians, ed. Jehuda Reinharz and Daniel Swetschinski (Durham: Duke University Press, 1982), 49-66. See also Kreisel, Prophecy: The History of an Idea in Medieval Jewish Philosophy, 230-239, 260-262. Even some of the medieval philosophers, such as Nissim of Marseille, understood these phenomena in a naturalistic manner and maintained that Moses was the immediate author of the Law. For a discussion of this issue see chapter 6, 171-173; see also chapter 9. 
commandment word for word by means of an audible voice, nor was such a voice miraculously created by God for Israel's benefit at Sinai. ${ }^{13}$

When one turns to Maimonides' discussion of providence, an esoteric position, in essential agreement with Aristotle, is presented in a manner that borders upon the exoteric. Maimonides begins his discussion by indicating that according to the opinion of the Law, human beings possess free will and everything that befalls them, good and bad-whether a person is hurt by a thorn or receives even the slightest pleasure-is determined according to their just deserts (Guide 3.17). After presenting the view that posits personal divine intervention in all matters that befall human beings, he immediately modifies his view to indicate that individual providence, now treated as only the protection humans experience and not the calamities that befall them, is in proportion to the perfection of the intellect, while everything else that happens to them is by chance, as is the case with the other species (Guide 3.18). Maimonides leads us step by step to the conclusion that the intellect itself is the mode of providence given to human beings, since it allows the individual to anticipate most evils and to take action to avoid them. It also directs the individual to lead a lifestyle that minimizes the physical evils normally befalling human beings. Finally, the perfect individual has attained an identity of pure intellect, in whose case all physical evils that befall the corporeal aspect of his being no longer affect him. ${ }^{14}$ The fact that Maimonides in his commentary on Job distinguishes Elihu's opinion, ostensibly representing Maimonides' own, and the opinion of

13 See Howard Kreisel, "The Voice of God in Medieval Jewish Philosophic Exegesis," Daat 16 (1986): 29-38 (Heb.). See also Jacob Levinger, Maimonides as Philosopher and Codifier (Jerusalem: Bialik Institute, 1989), 39-48 (Heb.). I discuss this issue in more detail below, chapter 9, 342-348.

14 A number of scholars have convincingly argued this reading of Maimonides. See, for example, Alvin Reines, "Maimonides' Concepts of Providence and Theodicy," HUCA 43 (1972): 169-206; Charles Touati, "Les deux théories de Maïmonide sur la providence," in Studies in Jewish Religious and Intellectual History, ed. Siegfried Stein and Raphael Loewe (Alabama: Alabama University Press, 1979), 331-344. This position was advanced by Maimonides' earliest commentators. See the interpretations of Maimonides' remarks on providence presented by Samuel and Moses Ibn Tibbon published by Zevi Diesendruck, "Samuel and Moses Ibn Tibbon on Maimonides' Theory of Providence," HUCA 11 (1936): 341-366. See also below, chapter 4, 96; chapter 11, 415. 
Eliphaz, which he treats as false and equates with the opinion of the Law (Guide 3.23), hardly leaves any doubt that Maimonides eschews the view of God's immediate role in extending providence to individuals. The intellect is the human being's guardian angel, while Satan, representing the privations associated with matter, is powerless to affect the perfect immortal intellect. ${ }^{15}$

As for miracles, Maimonides' position on how to understand them is far from clear. In the case of the most important miracle associated with the faith, namely, the resurrection of the dead-leaving aside the Revelation at Sinai, which Maimonides treats as a unique event belonging to a different category altogether ${ }^{16}$ - he apparently did not accept a literal understanding of resurrection, his disclaimers to the opposite in his Treatise on Resurrection notwithstanding. The immortality of the perfect intellect is the only form of "resurrection" that Maimonides recognizes. This is at least the conclusion that appears upon a close reading of all his pronouncements on the subject. ${ }^{17}$ Other miracles he seems to regard as anomalies in nature. I have argued elsewhere that he may even have accepted the view that the prophet himself is the author of some of the miracles, ${ }^{18}$ though the evidence for this view is admittedly sketchy at best.

Overall, there is a good deal of scholarly literature on each of the topics mentioned above providing a strong basis for arguing that

15 For an in-depth study of Maimonides' commentary on Job, see Robert Eisen, The Book of Job in Medieval Jewish Philosophy (Oxford: Oxford University Press, 2004), 43-77. See also Hannah Kasher, "The Image and Views of Job in the Guide of the Perplexed," Daat 15 (1985): 81-89 (Heb.).

16 See Mishneb Torah, Laws of Principles of the Torah 8.1. Maimonides agrees that miracles occurred at Sinai, but the voice heard at Sinai is not to be placed in the category of miracles; see Guide 2.33. See also Kreisel, Prophecy: The History of an Idea in Medieval Jewish Philosophy, 191-195, 230-232.

17 For an esotericist reading of Maimonides' treatise see, for example, Robert Krischner, "Maimonides' Fiction of Resurrection," HUCA 52 (1982): 163-193.

18 Avicenna advances this theory, which in all likelihood was known to Maimonides. See my "Miracles in Medieval Jewish Philosophy," Jewish Quarterly Review 75 (1984): 106-114. See also below, chapter 9, 354-360. For a discussion of Maimonides' approach to miracles, see also Hannah Kasher, "Biblical Miracles and the Universality of Natural Laws: Maimonides' Three Methods of Harmonization," Journal of Jewish Thought and Philosophy 8 (1999): 25-52. 
Maimonides held an esoteric position. ${ }^{19}$ Hence, when one looks at the issues Maimonides discusses after he lays down the doctrine of creation, one sees not only that on the exoteric level, after showing God's volition to act freely and in a direct manner, he "makes only sparing and very cautious use of this possibility," in the words of Guttmann; one also sees reasons for questioning whether he made any use of this possibility at all. If one accepts the evidence for an esotericist reading of Maimonides on these issues-certainly a big "if" for those who have not closely examined the issues, or have done so and remain unconvinced-one arrives at a strange conclusion: Maimonides believes in creation on religious as well as philosophic grounds, but treats the divine governance of the world, including the phenomena associated with revelatory religion, in a manner that is in complete harmony with the philosophic world view. Let us keep in mind that Maimonides had before him the model presented by Alfarabi, a philosopher he greatly admired, who explained revelation and the fundamental doctrines of revelatory religion in a naturalistic manner. ${ }^{20}$

It is true that Maimonides labels creation the most important principle of the Law after the unity of God (Guide 2.13). It is not difficult to discern why: his appreciation of the fact that the vast majority of believers could not accept the divine origin of the Torah without belief in creation. ${ }^{21}$ It is no wonder that Maimonides works hard to defend this belief, given the stakes involved. After writing the Guide, he goes so far as to reformulate the fourth principle-God's eternal

19 It should be noted that Herbert Davidson in his book, Moses Maimonides (above, n. 2) chose to ignore many of the stronger arguments for an esotericist reading of Maimonides while dismissing this reading out of hand.

20 See, for example, Alfarabi's description of the laying down of perfect law in The Political Regime, translated by Fauzi Najjar in Medieval Political Philosophy, ed. Ralph Lerner and Muhsin Mahdi (Ithaca: Cornell University Press, 1972), 36-37. The theological doctrines of revelatory religion are treated by Alfarabi as philosophic truths presented in a figurative manner. For the influence of Alfarabi on Maimonides' views on the origins and function of revelatory religion and its relation to philosophy, see in particular Lawrence Berman, "Maimonides, the Disciple of Alfarabi," Israel Oriental Studies 4 (1974): 154-178.

21 One may further argue that many would even question the very existence of God without belief in creation, as Maimonides' comments in Guide 2.31 imply; see above, n. 9. 
existence-of the thirteen principles of the faith that he had laid down in his Commentary on the Mishnab: Introduction to Pereq Heleq to include creation. According to the original formulation, which stresses the unique nature of the eternity of God, one could accept this principle while still believing in the eternity of the world, as he himself indicates in his reformulation. ${ }^{22}$

Up to this point in the argument I have not made any direct case for interpreting Maimonides as believing in eternity. My argument has simply been that if Maimonides holds an esoteric position regarding a number of major theological issues-a position that is far easier to prove-then at least one has grounds to wonder if the same is not the case for creation. This is not simply to claim that an esoteric stance on one issue inevitably implies esoteric positions on other issues as well. In this case, the issue of creation is the fundamental one underlying the other issues. Hence if Maimonides maintained an esoteric position on the major "derivative" issues, one has good reason to suppose that this is the case with the core issue. Moreover, Maimonides had every reason to present his true position on this issue in an even more veiled manner than he did on the others. By proving creation, Maimonides has removed the philosophic obstacles to a literal reading of Scripture on these issues, though he nevertheless rejects such a reading on many points quite explicitly. He could have utilized the doctrine of divine volition, which he has purportedly proven to advance a completely miraculous understanding of prophecy, more in keeping with a literal reading of Scripture, as well as a supernatural approach to divine providence, rather than treat them as esoteric doctrines belonging to the secrets of the Torah that are not to be understood in accordance with a literal reading of Scripture (Guide 1.35). Given this fact, one at least has a basis for wondering whether Maimonides' adoption of an esoteric

22 For a discussion of this point, see Howard Kreisel, Maimonides' Political Thought (Albany: SUNY Press, 1999), 217-221. The original formulation, God's absolute eternity, appears to be predicated on Avicenna's notion of God's necessary existence-namely, God's essence is the cause of His existence. Hence even if other entities are eternal, their eternity is not of the same nature as that of God, since they possess only possible existence. They require an external agent, namely God, to actualize this possibility. 
position is not also the case with the doctrine of creation. As we have seen, one can easily understand why, from a political-pedagogical perspective, Maimonides would publicly uphold the doctrine of creation even if privately he did not agree with it.

\section{The Esotericist Reading of Maimonides' Position on Creation}

The textual evidence in support of the interpretation that Maimonides believed in a world without beginning is certainly of a subtle nature, as the studies on this issue show. Maimonides' stated position in Guide 2.25 that if the eternity of the world would be proven demonstrably he could certainly interpret Scripture accordingly, just as he did in the case of the corporeal descriptions of God, which is a more difficult move from a textual standpoint, was picked up as early as the Middle Ages as a possible hint to an esoteric position, insofar as it makes the interpretation of Scripture subservient to human reason. Moreover, it is strange that Maimonides favors a literal reading of Scripture on a topic he characterizes as belonging to the secrets of the Law while on all other issues belonging to this category Maimonides chooses a figurative interpretation. ${ }^{23}$

The favorite piece of evidence for esotericists on the issue of creation relates to Maimonides' presentation of three opinions on prophecy in Guide 2.32 (God gives prophecy to whomever He chooses; prophecy is received by all those possessing the necessary preconditions and only by them; certain fixed conditions are necessary for attaining prophecy, but God can miraculously withhold prophecy from one who possesses all the necessary qualifications), explicitly comparing them to the three opinions he presents on the question of the creation of the world in Guide 2.13 (creation ex nibilo; creation from eternal matter; the eternity of the world). The mental gymnastics practiced by the exotericists, who tried to show that creation ex nibilo most closely corresponds to the opinion brought by Maimonides in the name of the

23 A similar point is made by Roslyn Weiss in her review of Seeskin, Maimonides on the Origin of the World (above, n. 5), Journal of the American Academy of Religion 75 (2007): 739. 
Law that prophecy is a natural phenomenon, which God at times miraculously withholds from the worthy, and that creation ex nibilo does not correspond to the opinion of the masses that God grants prophecy to whom $\mathrm{He}$ wills without the person possessing any fixed qualifications-a position Maimonides completely dismisses-simply is not convincing, particularly in light of the problematic nature of the other match ups between the opinions on creation and those of prophecy that result if one adopts this view. The doctrine of creation ex nibilo, which imposes no limits on God's volitional activity except for what is conceptually impossible, most clearly corresponds to God's ability to bestow prophecy upon whomever He wishes. ${ }^{24}$ Seeskin's suggestion that one should not look for a one-to-one match up is also problematic, since it does not account for why Maimonides would then point out the relation between the two subjects. ${ }^{25}$

One other frequently adduced bit of evidence for an esoteric position is Maimonides' apparent contradiction involving emanation. In 2.11 of the Guide he agrees with this doctrine (cf. 1.58 and 1.69), while in 2.22 he criticizes it in detail. Arthur Hyman and Herbert Davidson argue that there is no contradiction, since Maimonides could hold the view that the world begins emanating from God with the volitional act of creation, a doctrine that Alexander Altmann had shown is in fact the view of Isaac Israeli. ${ }^{26}$ Seeskin criticizes this view, ${ }^{27}$ correctly in my opinion, but I find his own view that Maimonides never really embraces the doctrine of emanation equally problematic. ${ }^{28}$ Maimonides alludes to his acceptance of the doctrine of emanation in the Mishneb Torah, Laws

24 For the bibliography dealing with this issue see above, n. 11.

25 See Seeskin, Maimonides on the Origin of the World, 178-179.

26 See Arthur Hyman, "Maimonides on Creation and Emanation," in Studies in Medieval Pbilosophy, ed. John F. Wippel (Washington, D.C.: Catholic University of America Press, 1987), 45-61; Herbert Davidson, Proofs for Eternity, Creation and the Existence of God in Medieval Islamic and Jewish Philosophy (Oxford: Oxford University Press, 1987), 208-209; Alexander Altmann, "Creation and Emanation in Isaac Israeli: A Reappraisal," in Studies in Medieval Jewish History and Literature (above, n. 11), 1-15.

27 Seeskin, Maimonides on the Origin of the World, 145-146.

28 Ibid., 119-120. 
of Principles of the Torah ${ }^{29}$ - where he also bases his abridged proof of God's existence and unity on the doctrine of the eternity of the world ${ }^{30}$ as well as other chapters of the Guide. ${ }^{31}$ The main criticism Maimonides presents against the doctrine of emanation in 2.22 focuses on the issue of how each Separate Intellect can be the source of emanation of a corporeal sphere. In other words, how can matter emanate from pure form? On this point, Maimonides' position in 2.11, where he embraces the doctrine of emanation, is less than clear and is worthy of a separate study. ${ }^{32}$

29 In Laws of Principles of the Torah 2.5, Maimonides writes: "In what manner are the Forms [Separate Intellects] separate from each other though they are not bodies? They are not equal in their existence but each one is below the level of the other and exists by virtue of his power [ve-hu mazui me-kobo], one above the other. All of them exist by virtue of the power of God and His goodness." This is a clear allusion to the doctrine of emanation, at least in regard to the Separate Intellects. Maimonides, however, does not allude to the immediate origin of the spheres in this context. See below, note 32 .

30 Maimonides bases his proof of the existence and unity of God on the Aristotelian notion of the eternal motion of the sphere; see Laws of Principles of the Torah 1.5, 7. In Guide 1.71, however, he explains this move as follows: "For this reason you will always find that whenever, in what I have written in the books of jurisprudence, I happen to mention the foundations and start upon establishing the existence of the deity, I establish it by discourses that adopt the way of the doctrine of the eternity of the world. The reason is not that I believe in the eternity of the world, but that I wish to establish our belief in the existence of God, may $\mathrm{He}$ be exalted, through a demonstrative method as to which there is no disagreement in any respect" (182). It is not clear that Maimonides' explanation in the Guide in fact represents his original intent in formulating his position in his legal works. For a discussion of this point, see Warren Z. Harvey, "The Mishneb Torah as a Key to the Secrets of the Guide," in Me'ah She'arim: Studies in Medieval Jewish Spiritual Life, ed. Ezra Fleischer et al. (Jerusalem: Magnes Press, 2001), 15-17.

31 In several passages in the Guide, Maimonides treats God as the source of emanation of the world; see $1.58,69 ; 2.6$.

32 In his brief presentation of the philosophic doctrine of emanation in 2.4, he does not explicitly attribute to the philosophers the doctrine that the spheres themselves emanate from the Separate Intellects-a doctrine that we find in Alfarabi and Avicenna, summarized by Halevi in the opening of the Kuzari, and subsequently brought by Maimonides in his critique of the philosophic position in 2.22. Rather Maimonides treats each Separate Intellect as the immediate agent of the intellect of each sphere. When he presents the doctrine of emanation in bis own name in 2.11, however, he appears to allude to the position that the Separate Intellects are also the source of the body of the spheres and not only the sphere's form or intellect. He writes: "For the overflow coming from Him, may he be exalted, for the bringing 
An examination of the terminology used by Maimonides regarding creation shows that the terms he employs are equivocal, or that he treats the biblical terms he explains as being equivocal. Nuriel has analyzed the term "creator" (al-bari) in the Guide, showing that Maimonides does not employ this term when dealing with the creation of the world but in contexts more in harmony with the notion of an eternal world, thereby alluding to an esoteric view in this matter. ${ }^{33}$ Sara Klein-Braslavy has shown that Maimonides interprets the Hebrew term for "create," bara', in an equivocal manner; it need not refer to creation ex nibilo but can refer to the emanation of form on matter, a doctrine that is in harmony with the notion of an eternal world..$^{34}$ Given Maimonides' view on the

into being of separate intellects overflows likewise from these intellects, so that one of them brings another one into being and this continues up to the Active Intellect. With the latter, the bringing in being of separate intellects comes to an end. Moreover a certain other act of bringing into being overflows from every separate intellect until the spheres come to an end with the sphere of the moon. After it there is the body subject to generation and corruption, I mean the first matter and what is composed of it" (275). In the latter passage it appears that only the question of the origin of sublunar matter is left open. Yet in a previous passage in the same chapter, he writes: ". . . that from the benefits received by the intellect, good things and lights overflow to the bodies of the spheres" (275). From this passage it appears that the bodies themselves do not have their origin in the Separate Intellects, only their form, and perhaps this is what Maimonides had in mind when he speaks of the emanation of the Separate Intellects that involves the bringing about of the spheres. This leaves open the problem of how Maimonides understood the origin of the bodies of the spheres, or of matter in general, if he did not in fact believe in the doctrine of creation ex nibilo. It appears that Maimonides at least entertained doubts regarding the emanation of matter from what is incorporeal, even if he favored the doctrine of the eternity of the world. One should add that the problem of whether the bodies of the spheres emanate from the Separate Intellects is discussed briefly in Averroes' Epitome to the Metaphysics. In this treatise, Averroes accepts the doctrine of emanation and sees in each of the Movers of the spheres the cause of the form (soul) of the sphere and the cause of a different Mover. As for the body of the sphere, he argues: ". . . the cause of the existence of the matters of the celestial bodies is nothing but their forms." See Rudiger Arnzen (trans.), Averroes on Aristotle's Metaphysics (Berlin: Walter de Gruyter, 2010), 169-175.

33 Avraham Nuriel, "The Question of a Primordial or Created World in the Philosophy of Maimonides," Tarbiz 33 (1964): 372-387 (Heb.) [reprinted in Nuriel, Concealed and Revealed in Medieval Jewish Philosophy (Jerusalem: Magnes Press, 2000), 25-40 (Heb.)].

34 Sara Klein-Braslavy, Maimonides' Interpretation of the Story of Creation (Jerusalem: Reuben Mass, 1987), 81-90 (Heb.). 
equivocal nature of biblical terms, it is more than plausible that he should hint to his esoteric views by means of the equivocal meanings of the terms he employs. He alludes to this technique in his admonition to the reader to "grasp each word that occurs in it in the course of the speech" of his treatise (Guide 1.introduction 15).

When one starts looking at the Guide with at least a suspicion that he holds an esoteric position, one finds more and more signs in support of this interpretation. Perhaps in some cases these readings can be attributed to the overly creative imagination of the interpreter, but I certainly do not think all of them can be so easily dismissed. It appears to me that Maimonides adopted a gamut of esoteric techniques to hint at his true view on this matter..$^{35}$ Let me present a few examples. ${ }^{36}$

One of the techniques for conveying an esoteric position is to attack a doctrine held by an opponent who does not belong to your "camp," though this doctrine essentially characterizes your own tradition's position. The average reader, even if he senses that there is a problem, will not pay too much attention to it since he is accustomed to

35 Herbert Davidson dismisses the strongest argument for Maimonides' esotericism-namely, that Maimonides explicitly indicates that he has incorporated contradictions in the Guide on purpose in order to veil his views-by arguing that Maimonides wrote the introduction before writing the bulk of his treatise; he subsequently changed his mind about using this technique, or any other, for masking his true views, which he proceeds to present quite openly. See Moses Maimonides (above, n. 2), 330, 391. Even if one accepts Davidson's view about the writing of the introduction, one need not accept his conclusion. Rather that retract his intention to write a treatise containing an esoteric level, Maimonides may have in fact developed additional strategies for alluding to his esoteric views.

36 See my "The Guide of the Perplexed and the Art of Concealment," in By the Well: Studies in Jewish Philosophy and Halakbic Thought Presented to Gerald J. Blidstein, ed. Uri Ehrlich, Howard Kreisel, and Daniel Lasker (Beer-Sheva: Ben-Gurion University of the Negev Press, 2008), 487-507 (Heb.). In this article I also deal with a number of additional techniques not described below. On the issue of esoteric writing I am very much indebted to Leo Strauss's masterful essay cited above, n. 3. There are no set rules for esoteric writing, for the premise of esoteric writing is that the reader will pick up on certain "irregularities" in the text, treat these irregularities as deliberate in character, and draw deductions regarding their purpose. Much then depends on the mind of the reader. Maimonides explicitly brings one such type of irregularity - arguments based on contradictory premises. As argued in the previous note, this technique hardly exhausts the possibilities for esoteric writing and the other techniques Maimonides may have chosen to employ. 
dismiss out of hand the truth of the doctrines of those who belong to different traditions. The careful reader, on the other hand, discerns that this attack hints at the fact that the author does not accept his own tradition's view on the matter. Maimonides appears to adopt this technique when he discusses one of the Kalām's positions, a theology of which he is exceptional critical. According to Maimonides, instead of exploring the major questions of speculation based on a profound understanding of the principles of reality, the Moslem theologians invent their principles in accordance with the criterion of how best to defend religious doctrines. ${ }^{37}$ In the course of presenting the Aristotelian proofs for the eternity of the world, in Guide 2.14 Maimonides presents the following argument:

He [Aristotle] asserts that with respect to everything that is produced in time, the possibility of its being produced precedes in time the production of the thing itself. And similarly with respect to everything that changes, the possibility of its changing precedes in time the change itself. From this premise he made a necessary inference as to the perpetuity of circular motion, its having no end and no beginning. His later followers in their turn made it clear by means of this premise that the world was eternal. They said: Before the world came into being, its production in time must have been either possible or necessary or impossible. Now if it was necessary, the world could not have been nonexistent. If its production in time was impossible, it could not be true that it ever would exist. And if it was possible, what was the substratum of this possibility? For there indubitably must be an existent thing that is the substratum of this possibility and in virtue of which it is said of the thing that it is possible. This is a very powerful method for establishing the eternity of the world. However, an intelligent man from among the later Mutalallimūn thought that he had solved this difficulty. He said: Possibility resides in the agent and not in the thing that is the object of action. This, however, is no reply, for there are two possibilities. For with respect to everything produced in time, the possibility of its being produced precedes in time the thing itself. And similarly in the agent that produced it, there is the possibility to produce that which it has produced before it has done so. There are indubitably two possibilities: a possibility in the matter to

37 Guide 1.71. 
become that particular thing, and a possibility in the agent to produce that particular thing. (287)

In the passage above, Maimonides presents an Aristotelian argument, brings the objection of the Kalām, and then brings the rebuttal of the philosophers to this objection, which he treats as successfully dismissing the objection. In order for something to be generated, there must exist two types of possibility. Maimonides himself in the previous chapter championed the opinion that the world was created ex nibilo, hence there existed no matter in which the possibility of the world resided. In a subsequent chapter, he dismisses the Aristotelian argument based on possibility as follows:

We shall make a similar assertion with regard to the possibility that must of necessity precede everything that is generated. For this is only necessary in regard to this being that is stabilized-in this being everything that is generated, is generated from some being. But in the case of a thing created from nothing, neither the senses nor the intellect point to something that must be preceded by its possibility. (2.17: 297)

According to Maimonides, the law that nothing is generated unless it is preceded by possibility found in matter only holds true after creation ex nibilo and is not an absolute law covering all conceivable existence. Thus God can create a world without there existing any substratum. The fact that Maimonides holds the view that there is an argument that rebuts the philosophic position on this issue raises the question of why he bothers to bring the argument of the Kalām against the philosophers only to then reject their argument. Ostensibly Maimonides' position is similar to the one they bring - namely, that there need not exist any matter supporting the possibility for creation and it is sufficient that God as agent possesses the capacity to create.

One may answer that Maimonides is critical of the Kalām because they were of the opinion that they were able to rebut the view of the philosophers based on the philosophers' own principles. Maimonides shows that they failed in this regard. Maimonides' own argument is not based on the principles of the philosophers, which he accepts, but upon 
a different principle-the difference between the laws of nature governing the world after it was formed and conceptual laws that necessarily characterize every activity, including divine activity. That everything generated must be preceded by a substratum that supports the possibility of generation is a physical law and not a logical one in his view. ${ }^{38}$ Thus Maimonides' argument against the philosophers is far different than the objection raised by the Kalām, despite a certain similarity between them.

There is, however, the alternative of interpreting Maimonides as alluding to an esoteric doctrine. By bringing the Kalām's argument in Guide 2.14, which appears to be extraneous to the discussion, since it belongs to his subsequent discussion and rejection of the philosophic arguments in chapter 17, Maimonides hints that he does not in fact accept the doctrine that he brings in chapter 13 and defends in chapter 17-God's ability to create the world ex nibilo. His rebuttal of the Kalām's argument, which arouses no problem in the average reader, while subsequently presenting an argument that essentially supports a similar position as the one advanced by the Kalām when defending the traditional position, is the way he signals to his more astute readers that he is not committed to the traditional view.

My second example is one in which a certain philosophic position is rebutted by the author, but then the rebuttal itself is answered by the author, essentially allowing the philosophic position to stand. In 2.22, in the midst of his critique of the doctrine of emanation, Maimonides ridicules this doctrine by claiming that it leads to the disgraceful conclusion: "it would follow that the deity, whom everyone who is intelligent recognizes to be perfect in every kind of perfection, could, as far as all

38 One should also note that in Maimonides' presentation of the philosophic position in Guide 2.14, he talks of the possibility in the agent if one posits creation, a point that he knows is conceptually impossible since no possibility can exist in God. This too is one of the arguments of the philosophers against creation. God's activity must remain constant through eternity. Maimonides acknowledges that this indeed is a great difficulty that he proceeds to address in Guide 2.18, though in a manner that is not completely convincing. The distinction between natural impossibilities (which are conceptually possible) and conceptual impossibilities underlies Maimonides' discussion of the impossible in Guide 3.15. 
the beings are concerned, produce nothing new in any of them; if $\mathrm{He}$ wished to lengthen a fly's wing or to shorten a worm's foot, He would not be able to do it" (319). In short, the deity of the Aristotelian philosophers is completely impotent-certainly a conclusion that no one is prepared to accept. What is significant in this case is Maimonides' next sentence, one in which he essentially undermines his own argument. "But Aristotle will say that He would not wish it and that it is impossible for Him to will something different from what is; that it would not add to His perfection but would perhaps from a certain point of view be a deficiency." Maimonides does not proceed to rebut Aristotle's counter-argument, as we would expect him to do, but allows Aristotle to have the last word on this matter, thereby subtly signaling his agreement with Aristotle's position. Indeed, for Maimonides, God created the world in a perfect manner, and thus He would not wish to introduce any change, certainly any permanent change, in what he created, Maimonides argues in 2.29. ${ }^{39}$

A third example of a possible allusion to an esoteric position on the issue of creation is a comment made in passing in 3.45 in his discussion of the reason for the image of two cherubim on the ark of the Law. Maimonides begins his discussion with the following remark: "It is known that the fundamental principle of belief in prophecy precedes the belief in the Law. For if there is no prophet, there can be no Law. The prophet receives prophetic revelation only through the intermediary of an angel" (576). Maimonides concludes: "Consequently it has been made clear that belief in the existence of angels precedes the belief in prophecy and the belief in prophecy precedes the belief in the Law." The question immediately arises of where in the picture one finds creation, which in Guide 2.25 was the basis for belief in the Law. This is exactly the point: one does not. Belief in angels upon which prophecy and the Law are dependent, that is to say belief in Separate Intellects and the faculties of the soul of the prophet, is in harmony with the doctrine of eternity. In short, one may believe in prophecy and the Law

39 Maimonides indicates there that God may wish to introduce temporary changes, i.e. miracles, for historical ends. His discussion in 2.22, however, appears to deal with the possibility of permanent changes. 
even if one does not believe in creation. Lest this point be completely lost on his readers, Maimonides repeats it in the continuation of his discussion: "Thus it has become clear through what we have stated before that the belief in the existence of angels is consequent upon the belief in the existence of the deity, and that thereby prophecy and the Law are established as valid ... this correct opinion, coming in second place after the belief in the existence of the deity, constituting the originative principle of belief in prophecy and the Law, and refuting idolatry, as we have explained" (577). Note that belief in angels does not simply supplement belief in creation in this context-it replaces it. No longer does creation come in second place after belief in the existence of the deity. ${ }^{40}$ This may well be an example of the seventh type of contradiction discussed by Maimonides in the introduction of his treatise:

In speaking about very obscure matters it is necessary to conceal some parts and to disclose others. Sometimes in the case of certain dicta this necessity requires that the discussion proceed on the basis of a certain premise, whereas in another place necessity requires that the discussion proceed on the basis of another premise contradicting the first one. In such cases the vulgar must in no way be aware of the contradiction; the author accordingly uses some device to conceal it by all means. (18)

The contradiction in the case of basing the Law on belief in angels as opposed to basing it on the world's creation is far from glaring, for belief in creation does not contradict belief in angels. The contradiction only becomes evident when one recalls that belief in angels (as Separate Intellects as well as the forces of nature) is in harmony with the philosophic view of the eternity of the world. Thus one may claim that the missing premise upon which Maimonides bases his remarks on Guide 3.45 is that the world is eternal. In this case, one can summarize the seventh form of contradiction as follows:

40 Maimonides speaks specifically of creation following the unity of God. It appears that he treats the existence and unity of God as essentially the same principle, though he divides them in his list of thirteen principles. 
Sometimes in the case of certain dicta this necessity [to defend the religion] requires that the discussion [in Guide 2.25] proceed on the basis of a certain premise [the creation of the world], whereas in another place [Guide 3.45] necessity [to present the truths of speculation] requires that the discussion proceed on the basis of another premise [the eternity of the world] contradicting the first one. In such cases the vulgar must in no way be aware of the contradiction; the author accordingly uses some device to conceal it by all means [he plants in the course of his discussion of the reasons for the commandments a remark that is in harmony with the eternity of the world-that belief in the existence of angels follows belief in God and is the basis for belief in the Law-in order to allude to his stance. The vulgar do not discern that the premise upon which his discussion is based contradicts the notion that the world is created].

A final example: as we have seen above, the most important theological reason that Maimonides advances for favoring the view that the world is created is that "with a belief in the creation of the world in time, all the miracles become possible and the Law becomes possible, and all that may be asked on this subject vanish. Thus it might be said: Why did God give prophetic revelation to this one and not to that" (Guide 2.25: 329)? Following is a list of additional questions whose answers are ostensibly based on belief in creation, such as: "Why did God give this Law to this particular nation, and why did $\mathrm{He}$ not legislate to the others; why did He legislate at this particular time and why did He not legislate before it or after; why did He impose these commandments and these prohibitions ... ?" The belief in creation allows one to answer all these questions in terms of a divine will that intervenes in history: "The answer to all these questions would be that it would be said: $\mathrm{He}$ wanted it this way or His wisdom required it this way" (329). Yet in his discussion of prophecy immediately following his discussion of creation, Maimonides in effect answers the question of why God gives prophetic revelation to one rather than another by upholding a naturalistic model-one who has attained all the conditions for prophecy receives the prophetic emanation and one who has not completed all the requirements does not. This suggests that a naturalistic model may also provide the answers to the other questions. Belief in creation is necessary for belief in the divine origin of the Law only in the case of the average 
believer, since his commitment to the Law hinges on viewing the revelation of the Law as a supernatural phenomenon.

\section{A Philosophic-Esotericist Reading of Maimonides' Position on Creation}

Despite the strength of Maimonides' philosophic arguments in favor of creation, there appear to be some flaws in his reasoning. Flaws in a philosophic argument in themselves certainly do not indicate an esoteric position. I would like to point out at least one flaw, however, that seems to involve a contradiction in Maimonides' own thought, perhaps signaling an esoteric position in accordance with the seventh form of contradiction.

Maimonides' version of the doctrine of particularization is different than the argument of Al-Ghazali against the philosophers in The Incoherence of the Philosophers, as Davidson has shown. ${ }^{41}$ Seeskin has picked up on this point and elaborated upon it. ${ }^{42}$ In Al-Ghazali's version, particularization of the poles around which the spheres revolve or their direction of motion is the result of an arbitrary will. God's will is capable of choosing between two completely similar possibilities. Even according to the principles of the philosophers, Al-Ghazali says, It would make no difference whatsoever if two other equidistant points were chosen, rather than the North and South Poles around which the spheres rotate, or if the highest sphere moved from West to East rather than East to West, while the other spheres rotate in the opposite direction. ${ }^{43}$ Similarly, Al-Ghazali maintains that God can choose when to create a non-eternal world, though there is no difference between the possible moments of creation.

Once I can establish that things are particularized without any reference to wisdom, that wisdom has no role at all to play in certain choices, I can establish a meaningful notion of divine volition. The very

41 Herbert Davidson, "Argument from the Concept of Particularization in Arabic Philosophy," Philosophy East and West 18 (1968): 299-314.

42 Seeskin, Maimonides on the Origin of the World, 127-143.

43 Al-Ghazali, The Incoherence of the Philosophers, ed. and trans. Michael Marmura (Provo, UT: Brigham Young University Press, 2000), 1.48-64: 24-27. 
act of giving existence to the world, let alone when to give existence to the world, can be regarded as an arbitrary choice. There is no reason from the standpoint of wisdom to favor existence over non-existence.

Maimonides does not go this route, a route which in a crucial sense may be a more convincing way to prove creation. Rather, Maimonides appears to treat all divine decisions as reflecting purpose, and I interpret the notion of "purpose" in Maimonides' thought as an act reflecting the combination of wisdom and will. ${ }^{44}$ Maimonides frequently introduces the notion of divine wisdom and not will alone in dealing with the act of creation. ${ }^{45}$ Moreover, in 3.25 he treats all of God's actions as good and excellent, namely, "that accomplished by an agent aiming at a noble end, I mean one that is necessary and useful, and achieves that end" (503). ${ }^{46}$ Hence Maimonides feels that the direction and size of the spheres are not products of arbitrary will, but of an unfathomable divine wisdom. Maimonides' argument is that a carefully designed world in which all details have a purpose-that is to say, are the product of wisdom and will—can only be maintained if one regards such a world as having been created. An eternal world is a necessary one, in which all parts of heaven should be uniform, and not a world that reflects a wisdom guiding the will to act in a purposive-and not arbitrary-manner by giving existence to the many different qualities possessed by the heavenly bodies in accordance with the divine purpose (Guide 2.19-21). ${ }^{47}$ Moreover, it appears that for Maimonides the very act of choosing to create the world is a product of wisdom and not will alone, existence being preferable to non-existence. ${ }^{48}$

44 Guide 2.19; see Seeskin, Maimonides on the Origin of the World, 141-142.

45 Guide 2.18-19, 27, 29; 3.23, 25.

46 For a discussion of the concept "good" in Maimonides' thought, see Kreisel, Maimonides' Political Thought, 93-124.

47 Let me add parenthetically that even the details of the commandments are not arbitrary for Maimonides, despite his statement to the contrary in Guide 3.26; see Josef Stern, Problems and Parables of Law (Albany: SUNY Press, 1998), 25-33.

48 Maimonides' position on the purpose of the existence of the world in its entirety is ambiguous. He concludes Guide 3.13: "When man knows his own soul . . . his thoughts are not troubled by seeking a final end for what has not that final end; or by seeking any final end for what has no final end except its own existence, which depends on the divine will-if you prefer you can also say: on the divine wisdom" 
I find Maimonides' reasons for dismissing the possibility of an eternal creation of such a world in accordance with divine purpose unconvincing. I do not see why the two propositions, 1) that the world always existed and 2) that it is the product of divine purpose, are treated by Maimonides as irreconcilable, particularly in light of the otherness of divine wisdom and the activities resulting from it in Maimonides' thought. Why must purpose necessarily precede action and not exist with it simultaneously? Let us recall that one of the criticisms Maimonides aims against Aristotle is that the eternity of divine wisdom does not necessitate the eternity of the world since the unknowable divine wisdom may have regarded it as preferable to create a world having a temporal beginning (Guide 2.18). ${ }^{49}$ This argument, however, can be turned against Maimonides himself. The unknowable divine wisdom may have regarded it as preferable to create an eternal world according to the divine purpose. Eternal creation is certainly not a conceptual impossibility, so why dismiss this option? ${ }^{50}$ Furthermore, if existence is preferable to non-existence from the standpoint of wisdom, the option to create an eternal world appears to be the preferable one, at least from a human perspective.

Furthermore, if every divine choice for Maimonides is a product of wisdom, could God ever choose to act differently? Does not His very essence necessitate every choice? Only if we posit that there exist arbitrary choices, and the very purpose underlying the creation of the world as we know it is such a choice, can we escape this dilemma. Yet Maimonides, as I have argued, does not appear to accept the existence of arbitrary choices-all divine actions are good and excellent in reference to their ends and not only to their means (Guide 3.25), even if we do not always fathom the wisdom underlying them. In short, we have arrived at the conclusion that God could never act differently than $\mathrm{He}$

(456). Maimonides may be interpreted as saying that existence is a final end in itself, and the choice between existence and non-existence is not between similar possibilities from the perspective of divine wisdom.

49 For the inscrutability of divine wisdom, see also Guide 3.23.

50 Among later Jewish philosophers, Hasdai Crescas treats the doctrines of divine will and creation ex nibilo as in harmony with the doctrine of the eternity of the world. See Or Ha-Shem 3.1.5. 
does, He cannot choose either to will or not will something, for He can never act contrary to wisdom and all choices are the product of divine wisdom. Though Maimonides at times speaks of divine choices and God's ability to act in different ways, ${ }^{51}$ these "choices" appear to be purely theoretical and can never be actualized. The Aristotelian philosophers are accused by Maimonides of ascribing necessity to God by positing eternal creation (Guide 2.21), yet the necessity of creating a non-eternal world is the conclusion to which Maimonides' argument leads. The way out of this dilemma is to posit that necessity and volition are not necessarily contradictory terms and an act can be necessary from a certain perspective and volitional from another..$^{52}$ If this is the case, the obstacle for positing eternal creation is removed-the act of creating an eternal world is necessarily mandated by divine wisdom, yet at the same time it is a voluntary act not caused by any reasons external to God.

As I have already noted, a philosophic flaw in the argument in itself hardly points to an esoteric position. Contradictions in Maimonides' stance, however, may. In this case we can certainly point to an apparent contradiction. Maimonides argues, as we have seen, that what is eternal and not changing is necessary, and necessity and volition are mutually exclusive. This argument appears to be based on the Aristotelian principle that what is possible must be realized in the course of eternity. ${ }^{53}$ But does Maimonides consistently maintain this position? The answer is no. Consider Maimonides' position in regard to the destruction of the world. In 2.27 he writes:

However, in view of our claim, based on the Law, that things exist and perish according to His will, may He be exalted, and not in virtue of necessity, it is not necessary for us to profess that when $\mathrm{He}$, may He be exalted, brings into existence a thing that had not existed, He must necessarily cause this existent to pass away. Rather does the

51 See, for example, Guide 2.17: "And its Creator may, if He wishes to do so, render it [the world] entirely and absolutely nonexistent" (297).

52 See for example Crescas's discussion of human volition in Or Ha-Shem 2.5.5.

53 See Physics 3.4, 203b; Metaphysics 9.4, 1074b; cf. Guide 2.1 (third proof for the existence of God). 
matter inevitably depend on His will: if $\mathrm{He}$ wills, He causes the thing to pass away; and if $\mathrm{He}$ wills, $\mathrm{He}$ causes it to last; or it depends on what is required by His wisdom. It is accordingly possible that $\mathrm{He}$ should cause it to last for ever and ever and to endure as $\mathrm{He}$ Himself, may He be exalted, endures. (332-333)

The argument at first glance is simple. The Aristotelian natural principle that what is generated must also pass away ${ }^{54}$ does not hold in the case of the passing away of the world. Its continuous existence is due to divine will and not natural necessity, just as is the case with its creation. But this leaves us with the strange conclusion that what is eternal-the existence a parte post of the world-is not necessary but the product of volition. Let us formulate Maimonides' position in a slightly different manner: God could destroy the world but He never will. This certainly sounds like another way of saying that the eternal existence of the world is necessary. Isn't that what Maimonides maintained in reference to the eternity a parte ante of the world? If in regard to the future existence of the world eternity does not exclude volition, how can Maimonides deny that this is not also the case with the past existence of the world?

There is yet another passage where Maimonides treats an eternal action as the product of choice and not necessity. In his description of the spheres and Separate Intellects in 2.7, he writes: "they apprehend their acts and have will and free choice (iräda wa-'ikhtiyār) with regard to the governance committed to them, just as we have will (iräda) with regard to that which from the foundation of our existence has been committed to us and given over to our power. Only we sometimes do things that are more defective than other things, and our actions are preceded by privations; whereas the intellects and the spheres are not like that, but always do that which is good" (266). In short, volition on one hand and acting through eternity in the same manner without change in accordance with wisdom on the other hand, are not regarded by Maimonides as mutually exclusive propositions. Again we may ask,

54 Maimonides brings this principle also in Guide 2.14 (third method); see Aristotle, On the Heavens 1.12, 282a. 
why does Maimonides subsequently argue differently when it comes to the origin of the world? There seems to be different definitions of will and volition at the heart of Maimonides' different discussions, ${ }^{55}$ not all of them contradicting the notion of the willful creation of a world without beginning.

\section{Conclusion}

The problems and even contradictions in Maimonides' argument on behalf of creation that I have pointed out are probably not insurmountable and they should certainly not obscure the fact that Maimonides does present an excellent defense of creation. So why was Maimonides so philosophically ingenious in his defense of creation, if he did not really favor this doctrine from the standpoint of speculative truth? Perhaps he was interested in making an exceptional effort in hiding his esoteric position on this issue given his perception of the religious stakes involved. It was important for him to provide his co-religionists with good philosophical reasons to adopt creation in order to strengthen their commitment to the religious tradition. In short, what better defense against the philosophers can there be than by showing that their position not only conflicts with religion but also with philosophic reasoning, even if secretly Maimonides favored the philosophic position and felt that all the salient doctrines of tradition could be understood in accordance with the philosophic world view. At any rate, I think that the esotericist can only hope to show that there are valid reasons for adopting this interpretation of Maimonides' treatise in regard to the issue of creation, even if none of the arguments when taken individually are absolutely convincing. Given the strength of Maimonides' explicit defense of creation, that in itself is no small task.

55 For a detailed study of the two terms Maimonides uses for divine will-irāda and mash' 'ya-and the significance of his usage for the understanding of his philosophy, see Avraham Nuriel, "The Divine Will in More Nevukhim," Tarbiz 39 (1970): 39-61 (Heb.) [reprinted in Nuriel, Concealed and Revealed in Medieval Jewish Philosophy, 41-63]. 


\section{Appendix: The Platonic View of Creation from Eternal Matter and an Esotericist Reading of Maimonides}

In his article "Maimonides' Secret Position on Creation," argues against the esotericist interpretation of Maimonides. He indicates, however, that if one is prone to adopt an esotericist interpretation, it is far easier to defend the view that Maimonides agrees with the Platonic position of creation from eternal matter rather than with the Aristotelian position. In his book, Maimonides: The Life and World of One of Civilization's Greatest Minds, Joel Kraemer accepts this interpretation. ${ }^{57}$ There is much merit in the claim that the allusions to Maimonides' acceptance of the Platonic position are more manifest than those toward the Aristotelian one. In 2.13 he classifies the Platonic position with the Aristotelian one, arguing:

For they believe in eternity; and there is in our opinion no difference between those who believe that heaven must of necessity be generated from a thing and pass away into a thing or the belief of Aristotle who believed that it is not subject to generation and corruption. For the purpose of every follower of the Law of Moses and Abraham our Father or of those who go the way of these two is to believe that there is nothing eternal in any way at all existing simultaneously with God. (285)

While refraining from discussing the Platonic position in the following chapters, in 2.25 he adopts a different position altogether on how he views creation from eternal matter: "For if creation in time were demonstrated - if only as Plato understands creation —all the overhasty claims made to us on this point by the philosophers would become void. In the same way, if the philosophers would succeed in demonstrating eternity as Aristotle understands it, the Law as a whole would become

56 See above, n. 11.

57 New York: Doubleday, 2008, 382-387; see also 576-577, n. 153. Alfred Ivry argues that Maimonides accepts a Neoplatonized version of the Platonic view on this issue rather the Neoplatonized version of Aristotle's view; see Ivry, "Maimonides on Creation," Jerusalem Studies in Jewish Thought 9 (1990): 115-137 (Heb.). 
void, and a shift to other opinions would take place" (330).$^{58}$ Rather than identifying Plato's position with Aristotle, in that they both posit something coeternal with God, he now identifies Plato's position with the position of the Law, in that they both ascribe volition to God. Maimonides goes on in the next chapter to suggest that Rabbi Eliezer may have accepted the Platonic view, thereby showing that this view apparently had the sanction of a leading rabbinic authority. Maimonides' explicit position in 2.32 that prophecy is a perfection that God can miraculously withhold from the worthy individual most closely corresponds to the Platonic position that combines naturalism with divine voluntarism. One may add that some of Maimonides' intimations, mentioned above, to the eternity of the world can be viewed as much a support of the Platonic position as the Aristotelian one.

Several approaches may be adopted in dealing with the problem of why Maimonides appears to hint at two different positions regarding the world's eternity while explicitly upholding the doctrine of creation ex nibilo. One is to dismiss altogether the view that he favored the Aristotelian position. As we have seen, most of the allusions to his acceptance of Aristotle's view are exceptionally subtle and, it may be argued, originate in the mind of the interpreter rather than reflect Maimonides' true intent. His allusions to Plato's view, on the other hand, are more evident. The Neoplatonized version of Aristotle's view, which posits the emanation of matter from incorporeal being, was particularly problematic from a philosophic perspective, perhaps not less than the doctrine of creation ex nibilo. The doctrine of creation from eternal matter at least avoids this particular difficulty.

Another approach is to ascribe to Maimonides a quasi-skeptical position on this issue. He tended to accept the philosophers' view that matter must be eternal, but debated between the Aristotelian and Platonic positions. His hints toward both views allude to his uncertainty on this question.

A further approach, the one which I favor, is to view Maimonides as incorporating in his treatise levels of esotericism. He hints to both

58 There is an interesting parallel between Maimonides' statement and the position voiced by Halevi in Kuzari 1.67. 
the Platonic and Aristotelian positions because of the common denominator between these positions-an incorporeal God cannot create matter. He provides more overt allusions to the Platonic position insofar as it is a less problematic position from the standpoint of the masses' belief in the Law, while avoiding the major difficulty with the doctrine of creation ex nibilo. In short, it is a good compromise position for those readers who would find the Aristotelian position too radical, too greatly opposed to tradition, yet at the same time are disturbed by the traditional position from a philosophic perspective. For this reason, Maimonides employs a more moderate esotericism in alluding to it. ${ }^{59}$ Hence while he favors the Aristotelian position, his hints toward this position are far more subtle, to be grasped only by the most elite readers, because of its potential harm to the average believer. Of course one may argue that the exoteric reading of Maimonides is another alternative, but as I have tried to show, there are many good reasons for questioning this reading.

59 See Weiss, "Natural Order or Divine Will," 24-26. For the notion of different levels of exotericism/esotericism in Maimonides' Guide, see also Sarah KleinBraslavy, "Maimonides' Exoteric and Esoteric Biblical Interpretation in the Guide of the Perplexed," in Study and Knowledge in Jewish Thought, ed. Howard Kreisel (Beer-Sheva: Ben-Gurion University of the Negev, 2006), 137-164; Lawrence Kaplan, "Monotonically Decreasing Esotericism and the Purpose of The Guide of the Perplexed," in Maimonides after 800 Years, ed. Jay Harris (Cambridge, MA: Harvard University Press, 2007), 135-150. 
